JESTT Vol. 1 No. 2 Februari 2014

\title{
PROSES PENGAMBILAN KEPUTUSAN NASABAH BANK SYARIAH DALAM MEMILIH PRODUK PEMBIAYAAN KEPEMILIKAN RUMAH \\ (Studi Kasus Nasabah Bank Muammalat KCI Darmo Surabaya)
}

\author{
Bima Kurnia Putra \\ Mahasiswa Program Studi S-1 Ekonomi Islam - Fakultas Ekonomi dan Bisnis - Universitas Airlangga \\ Email: Bimakurniaputra63@gmail.com \\ Fatin Fadhilah Hasib \\ Departemen Ekonomi Syariah - Fakultas Ekonomi dan Bisnis - Universitas Airlangga \\ Email: fatin.fadhilah@gmail.com
}

\begin{abstract}
The purpose of this research is to find out the decision making process of the customer of Muamalat Bank in choosing mortgage product. The process comprises problem recognition, information search, evaluation of alternatives, product choice, and the outcomes.

A qualitative approach is applied in this research with the descriptive case study method. The collection of data uses purposive sampling to determine the key informant and uses snowballing sampling to determine the informants. The key informant in this research is an employee of Muamalat Bank. Meanwhile the infomants consist of four customers of Muamalat Bank. Two of them take murabahah contract and the rest takes musyarakah mutanaqisah contract. The collection of data is conducted through several steps including comprehensive exploration, focus exploration, and confirmation step. The data analysis in this research uses domain, taxonomic and componential analysis.

The result of this research shows that both the murabahah and musyarakah mutanaqisah customers had already passed through five steps in decision making process comprises problem recognition, information search, evaluation of alternatives, product choice, and outcomes. The difference between two of them is revealed in the problem recognition and the product choice. The customer choose the mortgage contract based on some features.

Keywords: Mortgage, decision making, murabahah, musyarakah mutanaqisah
\end{abstract}

\section{PENDAHULUAN}

\section{A. Latar Belakang}

Pembelian rumah dapat dilakukan secara tunai dan kredit. Ketika seseorang tidak memiliki cukup uang untuk membeli rumah dalam bentuk tunai, maka yang dilakukannya adalah dengan cara kredit atau berhutang. Solusi untuk mendapatkan rumah dengan harga terjangkau sesuai dengan pendapatan dan layak huni adalah Kredit Pemilikan Rumah (KPR). KPR merupakan fasilitas kredit kepemilikan rumah yang ditawarkan kepada konsumen karena ditunjukkan untuk konsumen maka disebut kredit konsumtif. Sedangkan lembaga keuangan yang memfasilitasi kredit atau pembiayaan kepemilikan rumah adalah bank

Bank Syariah juga menyediakan pembiayaan kepemilikan rumah seperti bank konvensional yang terlebih dahulu menawarkan penyaluran kredit pemilikan rumah (KPR). Secara garis besar KPR iB pada bank syariah dan konvensional memiliki fitur 
yang sama yakni pemberian produk kredit pemilikan rumah kepada konsumen atau nasabah. Namun juga memiliki perbedaan yang prinsipal yang di terapkan pada perbankan konvensional dan perbankan syariah. Akad pembiayaan kepemilikan rumah atau yang biasa disebut KPR Syariah didasarkan pada Al-Qur'an dan Hadist dan tidak didasarkan pada sistem bunga atau riba. Yogaswara (2010) mendefinisikan beberapa akad KPR syariah, yaitu KPR iB Jual Beli (skema murabahah), KPR iB sewa (skema ijarah), KPR iB Sewa Beli (skema ljarah Muntahia Bittamlik-IMBT), dan KPR iB Kepemilikan Bertahap (musyarakah mutanaqisah). Pada bank konvensional, KPR didasarkan atas sistem bunga, dimana sifat bunga berubah-rubah, jadi angsuran yang harus dibayarkan konsumen atau nasabah kepada pihak bank juga berubahrubah mengikuti tingkat fluktuasi bunga di pasar. Sistem bunga di larang oleh islam, karena bunga termasuk kedalam riba, dan bunga membuat ketidak pastian ekonomi kedepan, larangan riba terdapat pada surat Al-Baqarah ayat 275-276. Selain itu, sebagai seorang muslim dalam berperilaku konsumsi harus mempertimbangkan faktor kehalalan atas barang atau produk yang dikonsumsi tersebut, Allah SWT berfirman pada Al-Qur'an Surat An-Nahl ayat 114

Keanekaragaman akad yang ditawarkan pihak bank akan produk pembiayaan kepemilikan rumah berdampak kepada pilihan yang akan ditentukan oleh nasabah atau konsumen, akad-akad pembiayaan kepemilikan rumah yang ditawarkan bank Syariah di Indonesia tersebut diantaranya terdapat pada Tabel 1.1. Setiap akad memiliki karakteristik masing-masing yang menggambarkan kelebihan dan kekurangannya. Berikut jenisjenis akad kepemilikan rumah pada bank syariah di Indonesia.

Tabel 1.

Jenis Akad Kepemilikan Rumah Bank

Syariah

\begin{tabular}{|c|c|c|}
\hline Nama Bank & $\begin{array}{l}\text { Nama } \\
\text { Produk }\end{array}$ & Akad \\
\hline $\begin{array}{l}\text { BTN (BTN } \\
\text { Syariah) }\end{array}$ & $\begin{array}{l}\text { Pembiayaan } \\
\text { KPR BTN Ib }\end{array}$ & Murabahah \\
\hline $\begin{array}{l}\text { Bank } \\
\text { Bukopin } \\
\text { (Bank } \\
\text { Bukopin } \\
\text { syariah) }\end{array}$ & $\begin{array}{l}\text { Pembiayaan } \\
\text { iB } \\
\text { Kepemilikan } \\
\text { Rumah }\end{array}$ & Murabahah \\
\hline $\begin{array}{l}\text { Bank CIMB } \\
\text { Niaga (CIMB } \\
\text { Niaga } \\
\text { Syariah) }\end{array}$ & $\begin{array}{l}\text { iB Home } \\
\text { Ownership } \\
\text { Financing }\end{array}$ & $\begin{array}{l}\text { Murabahah } \\
\text { dan IMBT }\end{array}$ \\
\hline $\begin{array}{l}\text { Bank } \\
\text { Permata } \\
\text { (Permata } \\
\text { Syariah) }\end{array}$ & $\begin{array}{l}\text { PERMATA KPR } \\
\text { lb }\end{array}$ & Murabahah \\
\hline $\begin{array}{l}\text { Bank Jatim } \\
\text { (Bank Jatim } \\
\text { Syariah) }\end{array}$ & $\begin{array}{l}\text { KPR iB Griya } \\
\text { Barokah }\end{array}$ & $\begin{array}{l}\text { Musyarakah } \\
\text { Mutanaqishah }\end{array}$ \\
\hline $\begin{array}{l}\text { The } \\
\text { Hongkong \& } \\
\text { Shanghai BC } \\
\text { (HSBC } \\
\text { Amanah) }\end{array}$ & Home Plan iB & Murabahah \\
\hline BNI Syariah & $\begin{array}{l}\text { Griya iB } \\
\text { Hasanah }\end{array}$ & Murabahah \\
\hline $\begin{array}{l}\text { Bank } \\
\text { Muammalat } \\
\text { Indonesia }\end{array}$ & $\begin{array}{l}\text { Pembiayaan } \\
\text { Hunian } \\
\text { Syariah }\end{array}$ & $\begin{array}{l}\text { Murabahah } \\
\text { dan } \\
\text { Musyarakah } \\
\text { Muthanaqishah }\end{array}$ \\
\hline \multirow[t]{2}{*}{$\begin{array}{l}\text { Bank Syariah } \\
\text { Mandiri }\end{array}$} & $\begin{array}{l}\text { Pembiayaan } \\
\text { Griya BSM }\end{array}$ & Murabahah \\
\hline & $\begin{array}{l}\text { Pembiayaan } \\
\text { Griya BSM } \\
\text { Bersubsidi }\end{array}$ & Murabahah \\
\hline
\end{tabular}


JESTT Vol. 1 No. 2 Februari 2014

\begin{tabular}{|c|c|c|}
\hline & $\begin{array}{l}\text { Pembiayaan } \\
\text { Griya BSM DP } \\
0 \%\end{array}$ & Murabahah \\
\hline $\begin{array}{l}\text { Bank Mega } \\
\text { Syariah }\end{array}$ & KPR Utama iB & Murabahah \\
\hline BCA Syariah & KPR Ib & Murabahah \\
\hline BRI Syariah & $\begin{array}{l}\text { KPR BRI } \\
\text { Syariah iB }\end{array}$ & Murabahah \\
\hline $\begin{array}{l}\text { Bank Panin } \\
\text { Syariah }\end{array}$ & $\begin{array}{l}\text { Pembiayaan } \\
\text { Pemilikan } \\
\text { Rumah Pas iB }\end{array}$ & $\begin{array}{l}\text { Murabahah } \\
\text { dan } \\
\text { Musyarakah } \\
\text { Muthanaqishah }\end{array}$ \\
\hline $\begin{array}{l}\text { Bank Syariah } \\
\text { Bukopin }\end{array}$ & $\begin{array}{l}\text { Pembiayaan } \\
\text { iB } \\
\text { Kepemilikan } \\
\text { Rumah }\end{array}$ & Murabahah \\
\hline
\end{tabular}

di bank konvensional dapat dilihat pada tabel 1.2.

Tabel 2.

Jenis Produk KPR Bank Konvensional

\begin{tabular}{|c|c|c|}
\hline No. & Nama Bank & Produk KPR \\
\hline 1. & Bank BTN & $\begin{array}{l}\text { KPR BTN Sejahtera } \\
\text { FLPP } \\
\text { KPR BTN Platinium } \\
\text { Kredit Bangun Rumah } \\
\text { Kredit Agunan Rumah }\end{array}$ \\
\hline 2. & Bank Bukopin & KPR Bukopin \\
\hline 3. & $\begin{array}{l}\text { Bank CIMB } \\
\text { Niaga }\end{array}$ & $\begin{array}{l}\text { KPR CIMB Niaga X-Tra } \\
\text { KPR CIMB Niaga X-Tra } \\
\text { Manfaat } \\
\text { KPR CIMB Niaga X-Tra } \\
\text { Dinamis } \\
\text { KPR CIMB Niaga X-Tra } \\
\text { Luxury } \\
\text { KPR CIMB Niaga X-Tra } \\
\text { Cash }\end{array}$ \\
\hline 4. & $\begin{array}{l}\text { Bank } \\
\text { Permata }\end{array}$ & $\begin{array}{l}\text { Permata KPR } \\
\text { "Jaminan Proses KPR } \\
5 \text { Hari" } \\
\text { Permata KPR Bijak } \\
\text { Permata KPR cicilan } \\
\text { tetap } \\
\text { Permata Home } \\
\text { Ready Cash }\end{array}$ \\
\hline 5. & Bank Mandiri & $\begin{array}{l}\text { Mandiri KPR Duo } \\
\text { Mandiri KPR Take } \\
\text { Over } \\
\text { Mandiri KPR Top up } \\
\text { Mandiri KPR flexible } \\
\text { Mandiri KPR Angsuran } \\
\text { Berjenjang }\end{array}$ \\
\hline 6. & Bank Mega & Mega Griya \\
\hline 7. & Bank BCA & $\begin{array}{l}\text { Kredit Pemilikan } \\
\text { Rumah } \\
\text { KPR Refinancing } \\
\text { KPR Xtra }\end{array}$ \\
\hline 8. & Bank BRI & KPR BRI \\
\hline 9 & Bank Panin & KPR Panin \\
\hline 10. & Bank BNI & $\begin{array}{l}\text { Kepemilikan Rumah } \\
\text { BNI Griya }\end{array}$ \\
\hline
\end{tabular}

Banyaknya produk KPR yang ditawarkan bank konvensional maupun bank Syariah mendorong banyaknya pilihan 
alternatif konsumen untuk menjadi nasabah yang mengambil pembiayaan kepemilikan rumah. Pihak perbankan berlomba dalam menawarkan produk pembiayaan KPR unggulan demi mendapat respon baik pasar. Salah satu contoh adalah bank Muamalat, dalam menyalurkan pembiayaan kepemilikan rumah (KPR) bank Muamalat terbagi atas dua akad, yakni Murabahah dan Musyarakah Mutanaqisah (2013), peerkembangan penyaluran pembiayaan kepemilikan rumah oleh bank Muamalat tumbuh dengan pesat pada akhir tahun 2012, bank Muamalat berhasil meningkatkan penyaluran pembiayaan kepemilikan rumah sebesar 4,3 Triliun terhitung pada akhir tahun 2012.

\section{TINJAUAN PUSTAKA}

Keputusan pembelian barang atau jasa melibatkan dua pihak atau lebih (Suryani, 2008:13). Umumnya ada lima peran yang terlibat, yaitu :

a. Pemrakarsa (initator), yaitu orang yang $\mathrm{p}$

b. ertama kali menyarankan ide untuk membeli.

c. Pembawa pengaruh (influencer), yaitu orang yang memiliki pandangan yang mempengaruhi keputusan pembelian.

d. Pengambil keputusan (decider), yaitu orang yang menentukan keputusan pembelian.

e. Pembeli (buyer), yaitu orang yang melakukan pembelian secara nyata. f. Pemakai (user), yaitu orang yang mengkonsumsi dan menggunakan barang atau jasa yang dibeli.

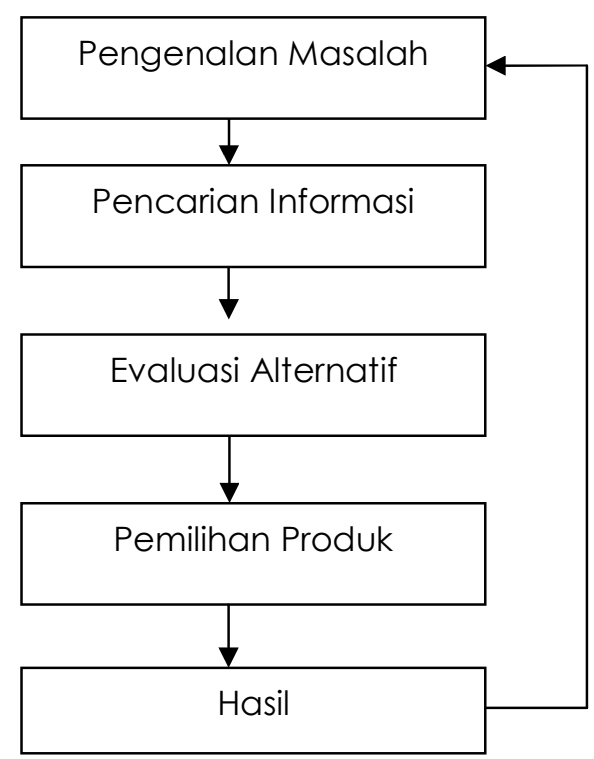

Gambar 1.

Model Pengambilan Keputusan

Gambar 2.1 menjelaskan secara ringkas bagaimana proses pengambilan keputusan oleh konsumen. Penjelasan tentang beberapa pendekatan yang digunakan konsumen ketika ia dihadapkan pada persoalan pembelian produk. Tiga tahapan penting dalam pengambilan keputusan : bagaimana konsumen mengenali permasalahan, atau kebutuhan akan suatu produk; pencarian informasi yang dilakukan konsumen berkaitan dengan produk yang akan ia pilih; dan cara konsumen mengevaluasi pilihanpilihan yang ada sehingga sampai pada suatu produk yang terpilih (Solomon, 
JESTT Vol. 1 No. 2 Februari 2014

2007:292).

Keputusan untuk membeli kebutuhan yang tidak terlalu penting biasanya dibuat oleh konsumen dalam waktu singkat, dengan informasi yang minimal. Sedangkan untuk memutuskan membeli kebutuhan yang lebih penting, rumah misalnya, seorang konsumen bisa menghabiskan waktu hingga seminggu penuh untuk mengumpulkan informasi dan mempertimbangkan semua pilihan yang ada (Allen, 2002:515).

\section{A. Sudut Pandang dalam Pengambilan Keputusan}

Proses pengambilan keputusan yang dilakukan oleh seorang konsumen sebenarnya merupakan proses pengulangan strategi (repertoire of strategies) dan juga pengevaluasian strategi yang digunakan sehingga ketika kelak seorang konsumen bisa menggunakan strategi yang tepat dalam mengambil keputusan tentang pembelian produk (Solomon, 2007;292). Proses ini disebut sebagai proses konstruktif (constructive processing). Hal ini dilakukan oleh seorang konsumen sehingga ia bisa membedakan mana kebutuhan yang harus dibeli dengan pertimbangan matang, mana kebutuhan yang bisa langsung dibeli tanpa banyak pertimbangan (Solomon, 2007;293).

Beberapa keputusan dibuat tanpa pertimbangan yang matang. Dalam kasus ini, seorang konsumen membeli produk sebagai responnya atas keadaan lingkungan. Seperti misalnya seorang konsumen membeli suatu produk karena produk tersebut ditata dengan cara yang menarik, atau seorang konsumen membeli suatu produk karena produk tersebut sedang didiskon dan promosi-promosi lainnya. Tipe keputusan yang diambil dengan cara ini dinamakan pengambilan keputusan behavioral (behavioral influence perspective).

Solomon (2007) menjelaskan beberapa keputusan lain dibuat dengan pertimbangan yang matang, namun tetap tidak bisa dijelaskan dengan akal sehat. Seperti selera musik seseorang, atau ketika seorang konsumen memilih untuk membeli suatu karya seni tertentu. Tidak ada penanda khusus yang bisa digunakan untuk menilai apakah suatu produk itu baik atau kurang baik karena pilihan ini sifatnya subjektif. Hal yang dapat dilakukan oleh seorang marketer adalah dengan menawarkan jasa dan fasilitas sebaik mungkin kepada konsumen yang telah memilih produknya. Tipe pengambilan keputusan yang didasarkan pada ketotalan fasilitas yang ditawarkan sebuah produk dinamakan pengambilan keputusan berdasarkan pengalaman (experiental perspective) (Solomon, 2007;293).

\section{B. Mengenali Permasalahan}

Ketika seorang konsumen menyadari bahwa hal-hal yang dimilikinya tidak lagi memenuhi standar atau tidak lagi 
JESTT Vol. 1 No. 2 Februari 2014

memenuhi hasratnya, maka konsumen tersebut sedang berada dalam bagian pertama dari proses pengambilan keputusan yaitu mengenali permasalahan. Seorang konsumen mengenali adanya masalah yang harus diselesaikan, baik itu masalah kecil, ataupun masalah yang lebih kompleks. Misalnya, seseorang yang kehabisan bahan bakar di jalan raya merasa kecewa dengan mobil yang dibelinya, meskipun mobil tersebut tidak mengalami kerusakan mesin. Masalah dapat berkembang melalui salah satu dari dua cara. Dalam kasus seorang konsumen yang kehabisan bahan bakar, keadaan saat ini (actual state) si konsumen sedang menurun. Sedangkan, ada seorang konsumen lain memiliki mobil yang lebih canggih dan baru, maka kondisi ideal (ideal state) orang tersebut akan naik (opportunity recognition). Sementara itu, kesenjangan terjadi karena adanya perbedaan antara actual state dan ideal state (Solomon, 2007;296).

Kebutuhan untuk diakui (need recognition) dapat terjadi dalam beberapa cara. Kualitas actual state seseorang dapat dikurangi dengan cara meninggalkan produk, dengan membeli sebuah produk yang tidak cukup memuaskan, atau membuat diri kita membutuhkan produk lain (misalnya, membeli rumah akan membuat keinginan kita untuk membeli barang-barang lain akan hilang, karena fokus utama kita adalah mengisi rumah tersebut dengan perabotan). Opportunity recognition sering terjadi ketika seorang konsumen berhadapan dengan produkproduk yang memiliki kualitas yang lebih baik. Hal ini terjadi karena kebutuhan seseorang berubah; ketika seorang mahasiswa berubah menjadi seorang pekerja, maka ia akan membutuhkan barang-barang yang berbeda untuk beradaptasi dengan lingkungannya (Solomon, 2007;296).

\section{Mencari Informasi}

Setelah permasalahan disadari, konsumen memerlukan beberapa informasi untuk digunakan memecahkan masalah. Proses mencari informasi adalah proses dimana seorang konsumen mengamati lingkungan sekitarnya untuk mengumpulkan data-data yang ia perlukan untuk membuat suatu keputusan yang rasional. Seorang konsumen mungkin menyadari bahwa ia perlu menyelidiki pasaran untuk mendapatkan informasi-informasi yang spesifik. Proses ini dinamakan purchase search (pencarian informasi berkenaan dengan suatu barang dengan tujuan untuk membeli barang tersebut). Di sisi lain, konsumen yang telah berpengalaman dalam berbelanja, hanya mencari informasi tentang produk yang akan mereka beli untuk kesenangan saja atau mereka hanya ingin mendapatkan informasi terbaru tentang hal-hal yang terjadi di pasaran.

a) Pencarian Internal dan Pencarian Eksternal 
Secara garis besar, sumber-sumber informasi dapat dibagi menjadi dua tipe: Pencarian Internal dan Pencarian Eksternal. Pada dasarnya, kita sudah memiliki pengetahuan tentang produk-produk yang dijual di pasaran. Pengetahuan ini kita dapatkan dari pengalaman terdahulu, juga dari kebiasaan kita sebagai seorang konsumen untuk mengenali beberapa produk. Ketika kita hendak melakukan pembelian, biasanya kita akan menggali informasi yang ada di dalam ingatan kita untuk mencari alternatif pilihan lain. Namun, bahkan seorang konsumen yang sangat mengerti kondisi pasar akan tetap memerlukan informasi-informasi dari luar yang berupa iklan, saran dari teman, ataupun mempelajari pengalaman orang lain (Bloch, 1986;119).

b) Pencarian yang Disengaja dan Pencarian Tanpa-Disengaja

Pengetahuan kita akan suatu produk biasanya berasal dari pembelajaran langsung: kita pernah mencari informasi tentang suatu produk dan produk-produk lain yang sejenis. Misalnya, seorang ibu yang membelikan anak sulungnya kue ulangtahun untuk ulangtahunnya bulan lalu, kemungkinan juga akan membelikan kue ulangtahun yang sama untuk anak bungsunya yang berulangtahun bulan ini. Pada mulanya, kita mungkin tidak tertarik untuk membeli suatu produk, namun iklan yang muncul terus-menerus, kemasan yang menarik, dan promosi-promosi yang dilakukan akan membuat kita mengetahuitanpa-sengaja segala sesuatu tentang produk tersebut. Bagi para marketer, hal ini menguntungkan, karena konsumen akan mengingat tentang produk tersebut, dan akan langsung mengingat produk yang bersangkutan saat mereka membutuhkannya (Punch, 1987:71).

c) Ekonomi Informasi (The Economics of Information)

Sudut pandang yang umum dalam pengambilan keputusan adalah menganggap bahwa setiap informasi yang diperoleh bernilai ekonomi sehingga konsumen perlu mengumpulkan data sebanyak-banyaknya sebelum membuat keputusan. Asumsi ini dikenal juga sebagai asumsi yang utilitarian. Utilitarian juga menerangkan bahwa konsumen cenderung akan mengumpulkan informasi yang paling berharga lebih dulu (Simonson, 1998;566). Sedangkan informasi tambahan lainnya dikumpulkan hanya untuk menguatkan informasi yang telah didapatkan sebelumnya (Hauser, 1993;452). Konsumen juga bisa melakukan suatu proses pencarian alternatif produk lain yang dinamakan variety-seeking. Melalui proses ini, seorang konsumen bisa mencari alternatif-alternatif baru selain produkproduk yang telah familiar dengan mereka. Proses ini dapat mempengaruhi konsumen untuk beralih dari produk favorit mereka saat seorang kosumen merasa bosan dengan produk yang biasa mereka 
JESTT Vol. 1 No. 2 Februari 2014

gunakan (Rebecca, 1999;15).

\section{Mengevaluasi Pilihan}

Dalam memutuskan untuk membeli sebuah produk, seorang konsumen seringkali harus memilih satu dari sekian banyak pilihan. Dalam beberapa kasus, pilihan produk yang tersedia bisa mencapai ratusan. Keberagaman pilihan itu bisa saja berupa banyaknya merk yang menawarkan produk yang sama (seperti banyaknya merk rokok) atau satu merk yang memproduksi satu produk, tetapi dengan banyak variasi (seperti banyaknya varian warna dalam satu merk lipstik).

a) Mengenali Pilihan

Seorang konsumen yang memilih dengan lebih teliti, biasanya mengevaluasi lebih banyak merk dengan hati-hati, sedangkan konsumen yang memilih produk yang sudah mereka kenali biasanya tidak akan mempertimbangkan produk dari merk lain. Selain itu, beberapa bukti menunjukkan bahwa proses berpikir lebih panjang terjadi ketika terjadi kebingungan memilih diantara produk-produk yang bersaing. Konsumen akan dihadapkan pada pilihan yang sulit ketika ia menyadari bahwa pilihan-pilihan yang tersedia beresiko, tetapi akan mendatangkan keuntungan baginya jika ia memilih dengan tepat (Luce, 1997;384). Pilihan-pilihan yang dipertimbangkan oleh konsumen termasuk dalam daftar pertimbangan yang membandingkan produk-produk yang ada dalam ingatan dan produk-produk yang terlihat menonjol disekitarnya (Solomon, 2007;305). Daftar produk-produk yang dipertimbangkan oleh konsumen ini tidak panjang. Suatu studi dalam skala besar meneliti daftar produk yang dipertimbangkan konsumen dan hasilnya menunjukkan bahwa konsumen hanya mempertimbangkan beberapa pilihan saja, meskipun ada beberapa variasi dalam jenis produk dan asal negara. Misalnya orang-orang Amerika yang mengkonsumsi bir akan mempertimbangkan tidak lebih dari tiga, sedangkan orang Kanada rata-rata akan mempertimbangkan tujuh merk bir Hauser (dalam Solomon, 2007;305). Produk yang tidak masuk dalam daftar pertimbangan konsumen berarti telah dipertimbangkan sebelumnya, namun konsumen menolak memasukkan produk tersebut dalam daftar pilihan mereka. Konsumen cenderung memasukkan produk-produk baru dalam daftar pertimbangan disbanding produkproduk lama yang awalnya sempat dipertimbangkan, namun pada akhirnya tidak dipilih. Seorang marketer harus memastikan produknya dalam kondisi prima ketika diperkenalkan pada konsumen, karena konsumen enggan memberi kesempatan kedua pada produk yang tidak sesuai dengan keinginan mereka (Solomon, 2007;305).

b) Penggolongan Produk

Ketika seorang konsumen sedang membandingkan produk-produk yang ada, mereka akan membandingkan produk- 
produk yang sejenis (Solomon, 2007;306) .

c) Level Penggolongan Produk

Seorang konsumen menggolongkan suatu produk tidak hanya berdasarkan katagori yang sama, namun juga dengan level yang berbeda. Level penggolongan produk yang berbeda ini akan mempengaruhi keputusan seorang konsumen untuk memilih (Solomon, 2007;306). Dalam penggolongan level dasar, produk-produk yang dibandingkan memiliki banyak kesamaan sehingga range pilihan produk masih lebar. Level selanjutnya disebut sebagai Katagori Superordinat yang range nya lebih sempit dan level yang lebih spesifik disebut Katagori Subordinat dimana pada level ini konumen memperbandingkan suatu produk yang sejenis dari dua merk yang berbeda (Solomon, 2007;307).

\section{E. Kriteria Pengambilan Keputusan}

Setiap konsumen memiliki kriteria berbeda yang mereka terapkan sebelum mereka memutuskan untuk membeli suatu produk. Ada beberapa konsumen yang tidak terlalu rumit dalam memutuskan untuk membeli sesuatu, ada pula konsumen yang benar-benar mempertimbangkan banyak hal sebelum memutuskan untuk membeli sesuatu. Kriteria pengambilan keputusan ini dikelompokkan menjadi dua: yang bisa digantikan, dan yang tidak tergantikan (Solomon, 2007;320).

a) Kriteria yang Tidak Tergantikan (Noncompensatory Rules)
Konsumen akan mengeliminasi pilihan yang tidak memenuhi standar dasar yang mereka tetapkan sebelum membeli produk. Konsumen yang memiliki kriteria "hanya akan membeli barang-barang dengan merk yang sudah lama ada" tidak akan mempertimbangkan produk dari merk-merk baru meskipun produk mereka sama atau bahkan lebih baik kualitasnya (Park, 1976;114).

b) Kriteria Leksikografis

Kriteria leksikografis membuat konsumen memilih produk yang memiliki fitur yang menurut mereka harus ada dalam suatu produk. Jika ada dua atau lebih produk dari merk berbeda yang mempunyai fitur yang diinginkan konsumen, maka konsumen baru akan mempertimbangkan fitur-fitur lain yang ditawarkan (Solomon, 2007;320).

c) Kriteria yang Mengeliminasi Jika konsumen menginginkan suatu fitur dari suatu produk, maka produk-produk yang tidak memiliki fitur tersebut akan dicoret dari daftar pilih. Misalnya, seorang konsumen ingin membeli televisi yang mempunyai fitur sleep-timer akan mengeliminasi pilihan televisi yang tidak memiliki fitur sleep-timer (Solomon,2007:320).

d) Kriteria Konjungtif

Kriteria konjungtif biasanya diterapkan konsumen ketika ternyata ia tidak dapat menemukan produk yang memenuhi semua kriteria yang ia tetapkan. Biasanya, konsumen akan menunda 
keputusan untuk membeli barang hingga ia benar-benar menemukan barang dengan kriteria yang ia inginkan. Namun, konsumen juga bisa menurunkan standar atau mengubah kriteria sehingga ia dapat menoleransi beberapa kekurangan dan memilih produk yang menurutnya terbaik dari pilihan-pilihan yang tersedia (Solomon, 2007:320).

e) Kriteria yang Bisa Diganti (Compensatory Rules)

Konsumen yang menerapkan compensatory rules tidak mempunyai kriteria khusus untuk memilih produk yang ia butuhkan. la akan mempertimbangkan semua kelebihan dan kekurangan suatu produk.Peneliti mengelompokkan konsumen yang tidak memiliki kriteria khusus ini menjadi dua: yang menggunakan kriteria yang simpel (simple additive rule) dan yang menggunakan kriteria yang lebih rumit (weighted additive rule). Konsumen yang menggunakan kriteria yang simpel, memilih produk berdasarkan banyaknya kelebihan yang ada dalam satu produk. Sedangkan konsumen yang menggunakan kriteria yang lebih rumit selain mempertimbangkan kelebihan suatu produk, ia akan mempertimbangkan juga kegunaan dari fitur-fitur produk tersebut (Solomon, 2007:321).

\section{F. Pembiayaan Bank Syariah pada Kepemilikan Rumah}

Pembiayaan kepemilikan rumah oleh bank syariah umumnya terbagi atas beberapa akad transaksi yang dibentuk sesuai kebutuhan nasabah, diantara akad tersebut yaitu Ba'i Bithaman Ajil, ljarah Muntahia Bittamlik, Istisna wal Istisna, dan akadMusyarakah Mutanaqisah.

\section{G. Akad Al-Murabahah}

Akad Al-Merubahah adalah kontrak jual-beli atas barang tertentu, dalam transaksi jual-beli tersebut penjual harus menyebutkan dengan jelas barang yang diperjualbelikan dan tidak termasuk barang haram, harga pembelian dan keuntungan yang diambil dan cara pembayarannya harus disebutkan dengan jelas, apabila terjadi perubahan harga jual-beli maka akad tersebut menjadi batal (Arifin, 2006:22).

\section{Skema Pembiayaan Al-Murabahah}

Untuk skema dari akad Al-Murabahah, dapat dilihat dari skema berikut :

3

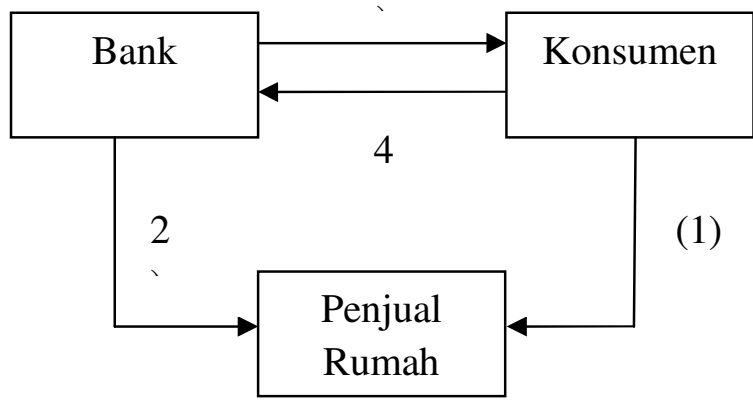

Gambar 2.

\section{Skema KPR Syariah akad Al-Murabahah}

Tahapan dari skema yang digambarkan di atas adalah sebagai berikut : 
1. Konsumen melakukan identifikasi dan memilih rumah yang akan dibeli

2. Bank membeli rumah dari penjual dengan cara tunai

3. Bank menjual rumah kepada konsumen dengan harga jual merupakan penjumlahan harga beli dengan besar keuntungan

4. Konsumen membayar rumah yang sudah dibeli oleh bank dengan cara mencicil.

Dari tahapan-tahapan tersebut, terdapat tiga kontrak perjanjian yang harus dilakukan agar akad Al-Murabahah ini dapat berjalan. Perjanjian pertama adalah Perjanjian Pembelian Properti (PBP), perjanjian ini melibatkan bank dengan penjual rumah yang mencakup pembelian properti yang dilakukan oleh bank dengan penjual rumah.

Yang kedua adalah Perjanjian Penjualan Property (PJP), yaitu perjanjian yang melibatkan bank dengan konsumen yaitu Bank menjual rumah kepada konsumen pada harga yang telah disepakati di dalam akad Al-Murabahah.

Perjanjian yang terakhir adalah Perjanjian Penjaminan (PP), yang melibatkan Bank dengan konsumen dalam hal penjaminan rumah. Konsumen menjaminkan rumahnya kepada bank sampai konsumen menyelesaikan pembayarannya.

\section{H. Akad ljarah Muntahia Bittamlik (IMBT)}

Terdapat bentuk akad lain yang bisa menjadi pilihan dalam melakukan pembiayaan perumahan secara syariah, yaitu akad ljarah Muntahia Bittamlik (IMBT). Akad ini merupakan akad sewa (ljarah) dari suatu aset riil, yaitu pembeli rumah menyewa rumah yang telah dibeli oleh bank, dan diakhiri dengan perpindahan kepemilikan dari bank kepada pembeli rumah. Di dalam akad IMBT ini terdapat dua buah akad, yaitu akad Jual-Beli (Al-Bai') dan akad IMBT sendiri yang merupakan akad sewa-menyewa yang diakhiri dengan perpindahan kepemilikan di akhir masa sewa (Karim, 2006:149).

\section{Skema Pembiayaan ljarah Muntahia Bittamlik (IMBT)}

Pada akad IMBT ini, proses dan tahapan kontraknya akan dijelaskan dengan menggunakan skema berikut :

(4)

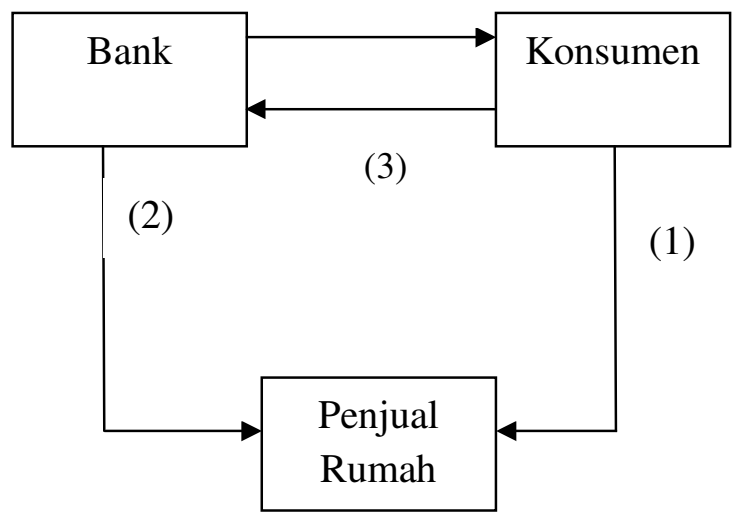

Gambar 3.

Skema KPR Syariah Akad IMBT 
Tahapan dari skema IMBT yang telah digambarkan di atas adalah sebagai berikut :

1. Konsumen melakukan identifikasi dan memilih rumah yang akan dibeli

2. Bank membeli rumah dari penjual dengan cara tunai

3. Bank menyewakan rumah kepada konsumen dengan harga sewa dan jangka waktu yang disepakati.

4. Konsumen membayar harga sewa rumah setiap bulan diakhiri dengan membeli rumah pada harga yang disepakati di akhir masa sewa.

Pada tahapan skema IMBT ini, terdapat tiga kontrak yang harus dilakukan. Kontrak pertama adalah kontrak antara bank dengan penjual rumah yang mencakup proses jual-beli rumah dari penjual rumah kepada bank. Kontrak ini diatur di dalam suatu Perjanjian Penjualan Properti (PJP).

Kontrak yang kedua adalah Perjanjian Sewa Menyewa (PSM), yaitu perjanjian yang melibatkan bank dengan konsumen, yaitu Bank menyewakan rumah kepada konsumen dengan biaya sewa per bulan dan jangka waktu sewa disepakati di dalam kontrak ini. Dan perjanjian yang terakhir adalah Perjanjian Jual Properti (PJP), yaitu bank menjual rumah yang disewakan tersebut kepada konsumen setelah masa sewa yang disepakati di awal berakhir.

\section{Akad Istisna wal Istisna}

Akad yang ketiga adalah akad Istisna yang merupakan salah satu pilihan bagi produk KPR. Akad Istisnaadalah akad jual beli dalam bentuk pemesanan pembuatan barang tertentu dengan kriteria dan persyaratan tertentu yang disepakati antara pemesan dan penjual (Karim, 2006:126). Sementara, akad Istisna wal Istisna merupakan gabungan dua akad istisna dalam suatu proses transaksi. Akad Istisna wal Istisna ini dapat diterapkan dalam kasus pembiayaan perumahan. Komponen harga dalam akad ini adalah harga awal yang dibutuhkan untuk membangun rumah, ditambah dengan biaya yang dikeluarkan oleh bank, serta keuntungan yang telah disepakati antara bank dan pemesan rumah di awal pengajuan pembiayaan.

\section{Skema Pembiayaan Istisna wal}

\section{Istisna}

Akad Istisna ini sangat mungkin dilakukan apabila rumah yang akan dibangun masih berada di bawah wewenang developer. Skema pada gambar 4 berikut ini adalah suatu skema yang dapat menjelaskan suatu proses bagaimana akad Istisna ini dilakukan. 
JESTT Vol. 1 No. 2 Februari 2014

3)

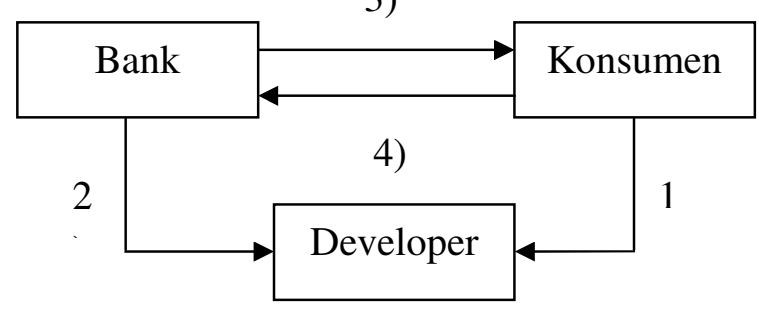

Gambar 4

Skema KPR Syariah Akad Ishtisna wal IStisna

Tahapan dari skema yang digambarkan di atas adalah sebagai berikut :

1. Konsumen melakukan identifikasi serta memilih lokasi tanah dan menentukan desain bangunan rumah yang diinginkan.

2. Bank melakukan pemesanan untuk membangun rumah kepada developer dengan cara melakukan pembayaran bertahap sampai rumah selesai dibangun.

3. Bank menjual jasa pembangunan rumah dengan mengambil keuntungan dari harga beli kepada developer.

4. Konsumen melakukan pemesanan untuk membangun rumah kepada bank dengan cara melakukan pembayaran bertahap sampai rumah selesai dibangun.

Tahapan-tahapan tersebut terdapat dua kontrak perjanjian yang harus dilakukan agar akadistisna ini dapat berjalan. Perjanjian pertama adalah Perjanjian antara bank dengan developer untuk memesan rumah yang harus dibangun terlebih dahulu sesuai pesanan dengan pembayaran bertahap yang diakhiri dengan perpindahan kepemilikan dari developer kepada bank.

Perjanjian yang kedua adalah Perjanjian antara bank dengan konsumen, yaitu konsumen memesan rumah yang harus dibangun terlebih dahulu. Bank akan melakukan pembangunan rumahnya dan konsumen melakukan pembayaran bertahap yang diakhiri dengan perpindahan kepemilikan dari bank kepada konsumen.

\section{J. Akad Musyarakah Mutanaqisah}

Akad yang terakhir yang dapat diterapkan untuk produk pembiayaan rumah adalah akad Musyarakah. Musyarakah merupakan suatu bentuk kerja sama antara dua pihak atau lebih untuk memiliki rumah, dengan membagi keuntungan dan kerugian sesuai dengan proporsi awal investasi, pada saat akad Musyarakah dilakukan. Meera (2005) menjelaskan akad MM ini dikatakan sebagai sebuah akad dengan konsep kemitraan berkurang. Mayoritas ulama Islam setuju dengan akad Musyarakah Mutanaqisah ini.

Tahapan dari skema adalah sebagai berikut :

1. Konsumen melakukan identifikasi serta memilih rumah yang diinginkan. 
JESTT Vol. 1 No. 2 Februari 2014

2. Konsumen bersama-sama dengan bank melakukan kerja sama kemitraan kepemilikan rumah sehingga bank dan konsumen sama-sama memiliki rumah sesuai dengan proporsi investasi yang dikeluarkan.

3. Konsumen membayar biaya sewa per bulan dan dibayarkan ke bank sesuai dengan proporsi kepemilikan.

4. Konsumen pun melakukan pembayaran kepada bank atas kepemilikan atas rumah yang masih dimiliki oleh bank.

\section{Skema Pembiayaan Musyarakah Mutanaqisah}

Skema pembiayaan untuk akad Musyarakah Mutanaqisah ini berupa kemitraan antara bank dan konsumen yang sama-sama memiliki kepemilikan di dalam rumah yang ingin dimiliki oleh konsumen.

Berikut adalah skema Musyarakah Mutanaqisah :

4

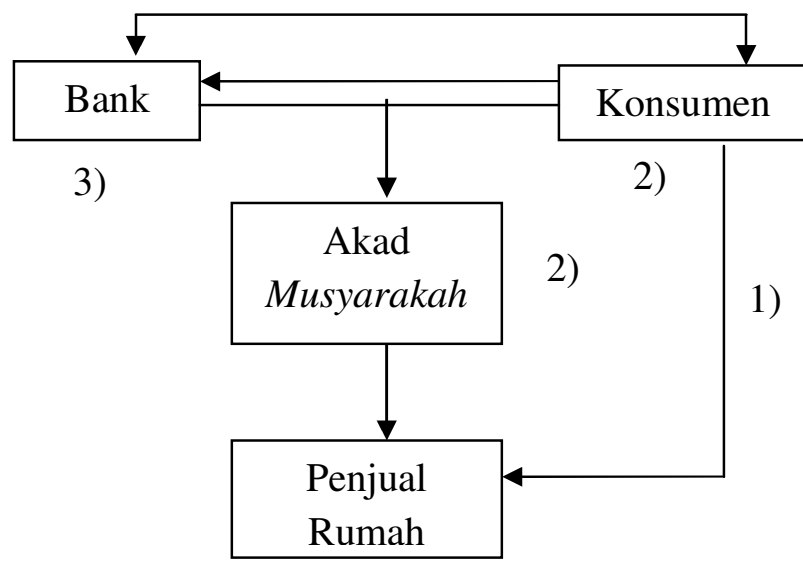

Gambar 5.
Skema KPR Syariah Akad Musyarakah Mutanaqishah

Dari tahapan-tahapan tersebut, terdapat dua kontrak perjanjian yang harus dilakukan agar akad Musyarakah Mutanaqisah ini dapat berjalan. Perjanjian pertama adalah Perjanjian kemitraan antara bank dengan konsumen, untuk bersama-sama memiliki sebuah rumah. Dan secara bertahap, konsumen akan membayarkan sejumlah dana yang disepakati untuk membeli status kepemilikan rumah yang dimiliki oleh bank.

Perjanjian yang kedua adalah Perjanjian sewa-menyewa (ljarah), yaitu konsumen membayar biaya sewa setiap bulannya kepada pemilik rumah. Karena pemilik rumahnya adalah bank dan konsumen, maka uang sewa tersebut harus dibagi sesuai dengan proporsi kepemilikan rumah tersebut. Dan aktivitas ini dilakukan sampai konsumen memiliki proporsi kepemilikan sebesar $100 \%$.

\section{METODE PENELITIAN}

Penelitian ini menggunakan pendekatan kualitatif. Strategi penelitian kualitatif yang digunakan dalam penelitian ini adalah studi kasus. Teknik penentuan sampel dalam penelitian ini menggunakan snowball sampling dan purposive sampling. snowball sampling yaitu teknik pengambilan sampel yang awalnya sedikit kemudian menjadi banyak sampai informasi yang didapatkan kredibel. Informan dalam penelitian ini adalah nasabah yang 
JESTT Vol. 1 No. 2 Februari 2014

mengambil KPR di bank Muamalat baik akad murabahah dan musyarakah mutanaqisah.

Ada tiga tahap analisis data yang digunakan dalam penelitian ini yaitu tahap analisis data di lapangan bersamaan dengan proses pengumpulan data, dan tahap analisis data sesudah di lapangan. Analisis data yang dilakukan selama di lapangan antara lain :

1. Analisis domain, digunakan untuk memperoleh gambaran dan pengertian yang menyeluruh tentang proses pemilihan akad di bank syariah oleh nasabah bank syariah. Hasil analisis berupa pengertian tentang perilaku konsumen nasabah bank syariah dalam memilih produk pembiayaan kepemilikan rumah.

2. Analisis taksonomi, yang dianalisis adalah struktur internal masing-masing domain dengan cara mengorganisasikan atau menghimpun elemen-elemen yang sama.

3. Analisis komponensial, yaitu menganalisis kontras-kontras struktur internal masingmasing domain. Hasil analisis ini akan dirangkum dalam diagram yang menunjukkan kontras-kontras dimensi yang diteliti.

\section{HASIL PENELITIAN DAN PEMBAHASAN}

\section{A. Model Pengambilan Keputusan}

\section{Nasabah Dalam Memilih Akad KPR iB}

Pada model pengambilan

keputusan nasabah dalam memilih akad
KPR iB murabahah dan msyarakah mutanaqisah terdapat persamaan dalam pengambilan keputusan yakni didasarkan pada kriteria need recognition dan opportunity recognition dalam memenuhi kebutuhan akan rumah.

\begin{tabular}{|c|c|}
\hline \multicolumn{2}{|c|}{$\begin{array}{l}\text { Pengenalan Masalah } \\
\text { Pada nasabah KPR bank Muamalat memiliki relatif kesamaan dalam } \\
\text { pengenalan masalah baik akad murabahah dan musyarakah } \\
\text { mutanaqisah yakni nasabah berusaha untuk meningkatkan kondisi } \\
\text { hidup aktual nasabah (actual state) kepada kondisi yang ideal (idal } \\
\text { state) dengan memiliki rumah. pembelian rumah tidak dapat } \\
\text { dilakukan secara tunai. }\end{array}$} \\
\hline Akad murabahah & Akad Musyarakah Mutanaisah \\
\hline $\begin{array}{l}\text { Nasabah kedua: need } \\
\text { recognition } \\
\text { Nasabah ketiga : oppurtinity } \\
\text { recognition }\end{array}$ & $\begin{array}{l}\text { Nasabah pertama : need } \\
\text { recognition } \\
\text { Nasabah keempat : need } \\
\text { recognition }\end{array}$ \\
\hline \multicolumn{2}{|c|}{$\begin{array}{l}\text { Pencarian Informasi } \\
\text { Pencarian informasi bersifat internal dan eksternal. Nasabah sebelum } \\
\text { memilih akad KPR bank Muamalat sebelumnya telah mengerti dan } \\
\text { memahami KPR, pencarian eksternal bertujuan agar informasi yang } \\
\text { didapatkan nasabah lebih jelas tentang produk, syarat dan biaya KPR } \\
\text { yang ditawarkan oleh pihak bank, termasuk mendapat informasi yang } \\
\text { lebih lengkap mengenai akad murabahah dan musyarakah } \\
\text { mutanaqisah di Bank Muamalat }\end{array}$} \\
\hline \multicolumn{2}{|c|}{$\begin{array}{l}\text { Evaluasi } \\
\text { Proses Evaluasi didasarkan kepada pemahaman nasabah tentang } \\
\text { sebuah produk KPR yang ditawarkan pihak bank konvensional dan } \\
\text { Syariah kemudian nasabah menggolongkan dan membedakan } \\
\text { produk KPR sesuai biaya dan risiko. Nasabah dengan akad } \\
\text { murabahah melakukan evaluasi dengan tolak Ukur risiko kredit yang } \\
\text { akan ditanggung dan tolak Ukur nasabah dengan akad musyarakah } \\
\text { mutanaqisah adalah uang muka yang rendah dan cicilan yang } \\
\text { ringan }\end{array}$} \\
\hline \multicolumn{2}{|c|}{$\begin{array}{l}\text { Pengambilan Keputusan } \\
\text { Pengambilan keputusan nasabah dalam memilih KPR terbagi atas } 3 \\
\text { kriteria yang berbeda yakni kriteria yang mengeliminasi, kriteria } \\
\text { leksikoglafis, dan kriteria konjugtif. }\end{array}$} \\
\hline Akad murabahah & Akad Musyarakah Mutanaisah \\
\hline $\begin{array}{l}\text { Nasabah kedua : kriteria } \\
\text { leksikoglafis } \\
\text { Nasabah ketiga : kriteria yang } \\
\text { mengeliminasi } \\
\text { Dengan mempertimbangkan } \\
\text { fitur: cicilan tetap, proses yang } \\
\text { mudah, dan angsuran sesuai } \\
\text { dengan kemampuan } \\
\text { nasabah. }\end{array}$ & $\begin{array}{l}\text { Nasabah pertama : kriteria } \\
\text { konjugtif } \\
\text { Nasabah keempat : kriteria } \\
\text { yang mengeliminasi } \\
\text { Dengan mempertimbangkan } \\
\text { fitur : vang muka yang rendah, } \\
\text { proses yang mudah, dan } \\
\text { besarnya cicilan yang ringan. }\end{array}$ \\
\hline \multicolumn{2}{|c|}{$\begin{array}{l}\text { Hasil } \\
\text { Dari pengajuan KPR yang diajukan nasabah telah disetujui } \\
\text { pembiayaannya oleh pihak bank Muamalat. Nasabah merasa } \\
\text { terbantu dengan adanya pemberian pembiayaan kepemilikan } \\
\text { rumah oleh pihak bank Muamalat. nasabah merasakan kepuasaan } \\
\text { atas produk dan pelayanan yang diberikan oleh pihak bank } \\
\text { Muamalat. Nasabah dalam memilih akad murabahah bukan } \\
\text { karena faktor mudah dipahami melainkan karena faktor risiko yang } \\
\text { rendah. }\end{array}$} \\
\hline
\end{tabular}


JESTT Vol. 1 No. 2 Februari 2014

Sumber: Hasil olah data

\section{Gambar 6.}

Model Pengambilan Keputusan Nasabah Dalam Memilih Akad KPR iB

Persamaan juga terdapat pada pencarian informasi secara internal dan eksternal. perbedaan proses pengambilan keputusan terdapat pada evaluasi dan pengambilan keputusan nasabah dalam memilih akad KPR ib bank Muamalat. Evaluasi nasabah bank Muamalat dengan akad musyarakah mutanaqisah didasarkan pada biaya uang muka yang rendah dan besarnya cicilan yang ringan sedangkan evaluasi nasabah akad murabahah didasarkan pada tingkat risiko yang rendah karena cicilan KPR iB murabahah bersifat tetap. Proses pengambilan keputusan nasabah didasarkan pada beberapa kriteria yakni kriteria yang mengeliminasi, eliminasi didapatkan oleh nasabah setelah melalui tahapan proses pengenelan produk (akad) KPR iB, penggolongan produk dan tingkat level penggolongan produk setelah melalui tahapan evaluasi. Kriteria Konjugtif, definisi kreteria tersebut yakni nasabah dalam pengajuan KPR menurunkan tingkat standar KPR yang nasabah inginkan sehingga nasabah menemukan produk yang mendekati kriteria yang nasabah inginkan. Kriteria leksikografis, nasabah dalam memilih produk (akad) KPR iB Muamalat harus mempunyai satu fitur yang ada didalam akad tersebut baik dari biaya dan persyaratan yang ada. Hasil dari pemberian KPR oleh bank Muamalat dirasakan positif karena adanya tingkat kepuasan pemilihan dan penggunaan akad serta layanan yang diberikan oleh pihak bank Muamalat. Nasabah dalam memilih akad murabahah karena faktor risiko yang rendah bukan karena faktor akad yang mudah dipahami, hal tersebut berbanding terbalik dengan proposisi penelitian.

\section{SIMPULAN}

Nasabah KPR iB bank Muamalat yang menggunakan akad murabahah dan musyarakah mutanaqisah sama-sama melewati kelima proses pengambilan keputusan yang terdiri pengenalan masalah, pencarian informasi, evaluasi, pengambilan keputusan dan hasil yang terdiri sebagai berikut :

1. pengenalan masalah nasabah akad murabahah didasarkan pada need recognition dan oppurtunity recognition seangkan kedua nasabah akad musyarakah sama-sama didasarkan need recognition.

2. dari keempat nasabah pencarian informasi dilakukan secara internal dan eksternal, informasi KPR akad murabahah dan musyarakah mutanaqisah sama-sama mudah dipahami nasabah saat melakukan pencarian informasi. 
3. proses evaluasi nasabah murabahah dan musyarakah mutaqisah samasama melalui proses pengenalan produk dan mengolongkan produk KPR sesuai uang muka, cicilan dan risiko kredit. Proses evaluasi pada nasabah akad murabahah didasarkan pada risiko kredit karena cicilannya terhitung tetap. Sedangkan proses evaluasi pada nasabah akad musyarakah mutanaqisah didasarkan pada vang muka yang rendah dan cicilan yang ringan.

4. proses pengambilan keputusan nasabah bank muamalat dalam memilih akad KPR murabahah dan musyarakah mutanaqisah terdiri dari beberapa kriteria yaitu kriteria yang mengeliminasi, kriteria leksikoglafis, dan kriteria kriteria konjugtif.

5. hasil dari pembiayaan dirasakan berdampak positif bagi nasabah, dengan disetujuinya pembiayaan nasabah merasa terbantu dengan upaya penyelesaian masalah kepemilikan rumah, kepuasan nasabah atas produk dan layanan yang diberikan oleh pihak bank muamalat menjadi nilai tambah positif bagi pihak perbankan.

Disamping kelima tahapan proses pengambilan keputusan tersebut didapati bahwa jumlah nasabah KPR iB di bank Muamalat terdapat pada akad musyarakah mutanaqisah dan nasabah yang mengambil akad KPR iB murabahah di bank Muamalat tidak didasarkan pada pemahaman akad yang mudah akan tetapi pada tingkat risiko yang rendah dan cicilan yang ringan.

\section{DAFTAR PUSTAKA}

Antonio, Muhammad Syafi'l. 2001. Bank Syariah Dari Teori Ke Praktik. Jakarta: Gema Insani.

Hasib, Fatin Fadhilah, Suprayogi Noven, Hapsari Meri Indri. 2012. Hibah Riset Fakultas Ekonomi dan Bisnis Universitas Airlangga:Implikasi Manajemen Risiko Terhadap Pemilihan Akad Pembiayaan Kepemilikan Rumada Pada Perbankan Syariah Surabaya.

Hausel, John R, Urban, Glen L, and Weinberg, Bruce D. 1993. Journal of Consumer Research: How Consumers Allocate Their Time When Searching for Information.

Kotler Philip and Amstrong, Gary. 2001. Principles of Marketing (Ninth Edition). New Jersey:Prentice Hall,Inc.

Kotler, Philip. 2006. Manajemen Pemasaran. Edisi Kesebelas. Jilid 1. Terjemahan Oleh Benyamin Moan. 2006. Jakarta:indkes.

Solomon, M. R. 2007. Consumer Behavior: Buying, Having, and Being. New Jersey, Upper Saddle River: Pearson Educatio n, Inc.

Yogaswara, Rhesa. 2010. Skema Pembiayaan Perumahan Syariah. Seminar Internasional IBFI Trisakti:Potensi Lembaga Keuangan Syariah Mikro Dalam Skema Pembiayaan Perumahan Secara Syariah.

Yin, Robert. 2002. Studi Kasus Desain dan Metode. Jakarta:PT Raja Grafindo Persada. 